Article

\title{
Inequality on the Increase: Trajectories of Privilege and Inequality in Madrid
}

\author{
Daniel Sorando *, Pedro Uceda and Marta Domínguez
}

TRANSOC-Instituto Complutense de Sociología para el Estudio de las Transformaciones Sociales Contemporáneas, Complutense University of Madrid, 28223 Madrid, Spain; E-Mails: dsorando@ucm.com (D.S.), puceda@ucm.es (P.U.), madoming@ucm.es (M.D.)

* Corresponding author

Submitted: 13 November 2020 | Accepted: 8 February 2021 | Published: 13 May 2021

\begin{abstract}
In Spain, housing is one of the main axes of social inequality. Its position within Spain's economic model and welfare system is key to understanding why its financialization at the beginning of the 21st century had such different consequences among residents as well as territorially. In this context, from 2001 to 2011, Madrid became one of the most segregated metropolitan areas in Europe. This article delves into how both housing and its location organise inequality in different social spheres and reproduce it over time. To this end, the geography of this inequality is analysed in different social residential trajectories, along with how segregation produces its own dynamics of inequality. The analysis is based on census data and applies a combination of factor and cluster analyses. The results reveal important processes of social residential marginalisation articulated by the interaction between high international immigration and the spatial manifestation of the housing bubble. The main socio-spatial result of this process is the disappearance of mixed social spaces in Madrid, previously located in the centre of the city. This dynamic produces opposite territories in terms of advantage and disadvantage in different spheres linked to social inequality such as education, health, leisure, care and even prejudice. In the process, impoverished immigrants disperse towards the neighbourhoods that concentrate the greatest disadvantages in each of these spheres.
\end{abstract}

\section{Keywords}

inequality; Madrid; privilege; residential marginalisation; segregation; social space; vulnerability

\section{Issue}

This article is part of the issue "Vicious Circle of Segregation: Understanding the Connectedness of Spatial Inequality across Generations and Life Domains" edited by Tiit Tammaru (University of Tartu, Estonia), Siiri Silm (University of Tartu, Estonia), Frank Witlox (Ghent University, Belgium), Maarten van Ham (Delft University of Technology, The Netherlands) and Madli-Johanna Maidla (University of Tartu, Estonia).

(C) 2021 by the authors; licensee Cogitatio (Lisbon, Portugal). This article is licensed under a Creative Commons Attribution 4.0 International License (CC BY).

\section{Introduction}

In major European metropolitan areas, residential segregation between socio-economic groups grew from 2001 to 2011 (Tammaru, Marcińczak, van Ham, \& Musterd, 2016). This dynamic goes hand in hand with an increase in economic inequality (Piketty, 2013). In the case of the metropolitan area of Madrid, this parallel increase was particularly outstanding. According to the comparison that Tammaru et al. (2016) made between the inten- sity of residential segregation between socio-economic groups in twelve European capitals, Madrid was situated at intermediate values at the beginning of the 21st century. However, ten years later, it was the most segregated metropolitan area. One of the consequences of the increase of segregation is the erosion of contact among unequal social groups. Even though the lines that define the structure of segregation among groups (socioeconomic position, ethnic origin, household cycle) have not changed in contemporary cities, 
the form of residential segregation has become increasingly more rigid (Marcuse \& van Kempen, 2002). In this process, socio-spatial processes progressively differentiate between dynamic and declining territories, thus questioning the existence of mixed social areas (Castells, 2003). Therefore, the territories of privilege and vulnerability are consolidated and disconnected socially and geographically. In this context, previous trajectories of socio-spatial mobility and mixing fade and urban space fragments into positions without interaction (Kesteloot, 2005). This socio-spatial division gives rise to unequal socio-economic contexts in different social domains which, in turn, condition the individual outcomes of its inhabitants (van Ham, Tammaru, \& Janssen, 2018). By this, we do not refer to the effects of the segregation of ethnic and social per se, whose relationship with social integration remains contested (Musterd, 2003; van Kempen \& Bolt, 2012), but to the material advantages and disadvantages that unequal urban contexts pose.

The case of Spanish cities during the first decade of the century, characterised by heavy suburbanisation facilitated by the intense financialization of housing, has been analysed in several studies (Antolín-Iria \& Fernández-Sobrado, 2020; Porcel \& Antón, 2020; Rubiales, 2020; Sorando \& Leal, 2019). However, the specific processes of socio-spatial change that sparked the increase in residential segregation during the first decade of the century have not yet been addressed in-depth, especially regarding these dynamics with a direct impact on its remaining socially mixed territories. Likewise, there is a gap in the empirical study of the effects of these dynamics on the reproduction of inequality in and through other spheres such as education, health, leisure, care and even prejudice (van Ham et al., 2018; Wacquant, 2008). These are to be the main contributions made by the present article, tracing the shifts in the relation between the social and spatial dimensions of inequality over a decade of significant increases in the financialization of housing. To this end, the article begins with a review of the relevant literature on the processes of segregation and inequality in urban societies in Southern Europe. The research strategy employed is then specified in the methodology section. Next, our results reveal the trajectories of privilege and vulnerability through which segregation and inequality have expanded and reproduced across Madrid's society and territory. Finally, the conclusions address the scenario that the analysis poses in the context of the subsequent decade.

\section{Processes of Segregation and Inequality in Southern Europe}

The literature on the relationships between social inequality and residential segregation has traditionally been dominated by concepts such as the ghetto or the neighbourhood effect, which are sometimes insuffi- cient to understand these relationships in all their complexity. Residential segregation in Southern European cities specifically gave rise to socio-spatial paradoxes that cannot always be understood through such concepts (Arbaci, 2019). Noteworthy among these paradoxes is the unstable relationship between inequality and segregation, a disparity that has also been observed in other contexts (Frey, 2014; Fujita \& Hill, 2012). In the case of Southern European cities at the turn of the century, several authors pointed to high levels of residential marginalisation in contexts with low intensity of residential segregation and an important social mix in their neighbourhoods, from both racial and socioeconomic perspectives (Domínguez, Leal, \& Martínez, 2012; Malheiros \& Fonseca, 2011). Recent research has demonstrated that this relationship underwent a transformation whereby both social inequality and residential segregation increased together once again in the first decade of the millennium (Sorando \& Leal, 2019). Therefore, finding residential segregation does not presuppose the discovery of its consequences on social inequality. Whether the two phenomena change together or not, what is revealed is the need to contextualise the relationships between the two concepts. In short, "rather than being an inevitable outcome or an organic phenomenon, segregation is the product of, and part of broader mechanisms and structures that (re)produce, social inequalities and (un)equal production of space in capitalist societies" (Arbaci, 2019, p. 42).

In the case of Spain, as a variant of the Mediterranean model, the familistic welfare regime gave housing a key role in the reproduction of its main structures. In this sense, promoting homeownership has been an instrument to promote the economy, rather than to reduce social inequalities. Specifically, tax relief for mortgage repayments on primary and secondary homes (which significantly benefits middle and high-income households) was the traditional instrument of housing policy in Southern European countries. Public spending on this policy has been applied to the detriment of public support for the working classes regardless of their tenancy classification (Allen, Barlow, Leal, Maloutas, \& Padovani, 2004). In societies with pronounced dualism in the labour market where the informal economy occupies an important position, owning a residence is imperative for household social security (Castles \& Ferrera, 1996). In this setting, solidarity strategies within the family are organised around the transmission of property assets across generations, legitimising the abandonment of social housing policy. In this regard, it is important to point out that two types of social housing have coexisted in Spain. The first type of social housing is the so-called viviendas de protección oficial, which is destined almost entirely to homeownership and is publicly subsidised through low-interest loans to private developers. More importantly, low-income households were systematically excluded from the distribution of viviendas de protección oficial, for which around $80 \%$ 
of households were eligible during the period considered in this article. The second type of social housing corresponds to its common use in the rest of Europe: rental social housing (Alberdi, 2014). In 2011, the distribution of tenure in Spain showed the consequences of this model: $79.6 \%$ of households lived in their own home compared to $12.1 \%$ who did so in rental housing at market price, and $2.8 \%$ in social rental housing (according to data from the Life Conditions Survey; see INE, 2011). In this context, Spain is the fourth country in the EU with the lowest percentage of social rental housing, only above Greece, Luxembourg, and Estonia (Pittini, 2019).

From the end of the 1990s, the financialization of this model expanded to the whole of Spanish society (Fernandez \& Aalbers, 2016; García-Lamarca \& Kaika, 2016). The deregulation of the mortgage markets during the 1980s and 1990s, in conjunction with the reduction in interest rates, allowed the expansion of the mortgage supply to sectors with less economic solvency, mainly migrants and young people: "Spanish 'subprimes' consisted in granting at least a million mortgages to vulnerable segments of society between 2003 and 2007" (López \& Rodríguez, 2011, p. 20). This promoted residential mobility until the outbreak of the great financial crisis in 2008 (Bayona \& Pujadas, 2014). Since then, the consequences of this model have made access to housing (both owned and rented) unimaginably difficult for some sections of society. Difficulties in accessing adequate and safe housing are, together with the low quality of employment, the main paths towards social exclusion in Spain. Therefore, social inequality is strongly linked to the Spanish residential model, due to the overburden that housing costs have on the economies of the most vulnerable households (FOESSA, 2019). This problem is serious for the two groups without access to family assets that were recipients of the subprime mortgages: most migrants (Arbaci, 2019) and many young households affected by economic precariousness (Bayrakdar, Coulter, Lersch, \& Vidal, 2019). In many cases, these households have been evicted from their mortgaged home or have been at risk (Cano, Etxezarreta, Dol, \& Hoekstra, 2013). In this context, a crucial savings strategy for them is the search for the cheapest housing in their metropolitan areas, which often involves a process of urban dispersion (Arbaci, 2019).

The territorial articulation of this welfare regime, in the current context of housing financialization, is based on the traditional patterns of residential segregation in Spanish cities. These trends can be interpreted as a variation of the quartered city model proposed by Marcuse and van Kempen (2000) according to the analysis of this phenomenon in the case of Madrid carried out by Sorando and Uceda (2018). Spanish cities' main distinguishing characteristic is the absence of widespread abandonment of urban centres, except in working-class areas in the process of gentrification. This characteristic is crucial because it had given rise to socially mixed urban centres at the beginning of the century. The peripheries of Spanish cities are segmented into three of the characteristic forms taken by the quartered city model: the suburban city, the tenement city of the post-war period and the tenement city of the late 20th century. The first is characterised by new middle classes, the second by both impoverished migrant populations and traditional working classes, and the third by autochthonous and ageing households. Lastly, two of the categories from the divided city model do not entirely coincide with the social geography of the Community of Madrid. They are the ethnic enclave, which appears only partially, and the abandoned city, which is even more divergent here, as the presence of the state is common even in the urban areas of increased social and residential vulnerability.

This scenario is, however, subject to the dynamics of socio-spatial change. According to van Ham, Manley, Bailey, Simpson, and Maclennan (2012), the main causes of social change in neighbourhoods are: (1) the behaviour of households that change neighbourhoods according to their preferences, resources and restrictions, (2) in-situ changes in the remaining population (in demographic and socio-economic terms) and (3) external impacts on neighbourhoods (such as structural socio-economic change and/or urban regeneration operations). In the case of Spanish metropolitan areas, the first two factors are related to the underlying characteristics of their segregation patterns, whereas the main external impacts involve two interconnected processes: the great international migratory flow beginning at the turn of the century and the different mutations of the financialization of housing in Spain, together with their unequal effect across the territory (Méndez, 2017; Rubiales, 2020).

All these dynamics reconfigure the geography of residential inequality, which has substantial effects on social inequity, as a result of the unequal position of different urban groups in property market dynamics. However, the manners in which different segregation trajectories reproduce social inequality are much broader. Following van Ham et al. (2018), segregation implies exposure to differential socio-spatial contexts that have specific effects on individual achievements and which, in turn, condition subsequent residential strategies. These contexts include housing and the neighbourhood of residence, but also places of work, leisure, education, and transport. In particular, the concentration of poor housing in certain neighbourhoods exposes its inhabitants to risks prevalent in other spheres such as health and education. In this respect, it makes sense to highlight three mechanisms for reproducing inequality through the social residential context. Firstly, the lack of available space in overcrowded dwellings is linked to psychological and school problems among children, as a result of the lack of space for study, the impact of high noise levels on concentration and sleeping difficulties (Solari \& Mare, 2012). Similarly, residence in buildings without a lift implies the social and physical isolation of many elderly and disabled people. Such isolation has significant effects 
on physical and mental health, well-being, and participation in social life (Holt-Lunstad, Smith, \& Layton, 2010). Finally, conditions for daily mobility are unevenly distributed across different territories and social groups as a result of the segregation of economic activities and the unequal ability of households to select their neighbourhood of residence, giving rise to inequalities in many areas including welfare, social inclusion and time availability (Church, Frost, \& Sullivan, 2000; Delbosc \& Currie, 2011; Kaufmann, Bergman, \& Joye, 2004).

\section{Methodology}

The analysis of the processes of socio-spatial change in the Community of Madrid from 2001 to 2011 and their effects on inequality was based on the Population and Housing censuses of 2001 and 2011 (INE, 2004, 2013). Since the 2011 census was not carried out as a thorough census (unlike the 2001 census), but rather by means of a sample, this census section cannot be used as a territorial unit of analysis. For this reason, the territory analysed has been divided into the largest number of territorial units possible while maintaining sufficient sample sizes to obtain statistically representative information for 2011. The procedure for drawing up these territorial units followed two criteria: The number of grouped census sections was established as eight, given that the resulting population size (an average of 13,063 residents) is the smallest that allows sociodemographic data to be obtained without high sampling errors, while the grouping of census sections was carried out following urban planning criteria so that each grouping includes sections mainly corresponding to the same urban planning category. To sum up, the 4,271 census sections of the Community of Madrid in 2011 were grouped into 488 aggregated territorial units (ATU), which were subsequently used as a reference to construct the census section groupings for 2001.

Taking this information as a starting point, a threestage research strategy was adopted. First, a multidimensional index of social residential inequality was developed which categorises each territory for both dates. To this end, factor analysis was used to synthesise the different dimensions tracing the structure of territorial resource distribution and the risks associated with social residential inequality. Each factor, therefore, measures a specific latent dimension of inequality at each ATU. The aim is to obtain stable factors for 2001 and 2011 so that each factor can be assumed to measure the same dimension in both years. For this investigation, we chose to include more variables than those of the classic three-factor model (social class, household life cycle and ethnic composition) used in the analysis of residential segregation in Western cities (Hartschorn, 1992). Along with the variables that make up these factors, this study incorporated other components that structure settlement patterns amid increasing uncertainties and precariousness (Standing, 2011) such as residential condi- tions, economic activity, type of contract and proximity to the place of work.

Secondly, the group of territories was classified into seven social residential types (SRT) for each year so that the most frequent trajectories between types could then be determined. To this end, a cluster analysis was applied to classify each ATU into an SRT according to its score on each of the factors in the social residential inequality index. In this way, the trajectories of each area can be observed from 2001 to 2011 through the classification of each ATU into a social residential trajectory according to its SRT of origin (in 2001) and the SRT it ends up in (in 2011). Of the 29 existing trajectories, the patterns of the trajectories accounting for over $3 \%$ of the total cases were analysed. This involved observing their transformation in the social residential inequality index dimensions.

Lastly, the average for a series of indicators of the specific processes involved in the reproduction of inequality linked to residential segregation was obtained in each of these trajectories. These indicators are space available (average surface area per person), the lack of time (percentage of workers who spend more than one hour commuting from their homes to their places of work) and potential physical isolation (percentage of people living in buildings of more than three floors without a lift). Although these variables were used in the social residential inequality index, the objective was to observe how their impact varies across different trajectories of social residential inequality.

\section{Results}

The empirical analysis of resident group settlement in the Community of Madrid in 2001 and 2011 confirms that their spatially differentiated locations are based on social and residential characteristics.

\subsection{Dimensions of Social Residential Inequality}

The social residential differentiation between residents in the Community of Madrid is a social process characterised by three dimensions that substantiate the classic model of western cities (Hartschorn, 1992) (see Table 1). Respectively, these factors explain $73.5 \%$ and $68.7 \%$ of the total variance of the set of variables included in 2001 and 2011. Also, the adjustment of both models is satisfactory on both dates (with KMO indices of 0.82 in 2001 and 0.85 in 2011 that confirm the suitability of the data for factor analysis, given the sufficient intercorrelation between the variables). The first dimension synthesises the socio-economic position of the residents of each ATU according to their occupation, their professional situation, and their level of education. This component, to be discussed in more depth below, is connected to some of the specific processes of inequality reproduction linked to residential segregation: lack of space and time availability, as well as physical isolation. Moreover, this dimension is bipolar, as it is made up of exclusionary 
Table 1. Composition of social residential differentiation factors in 2001 and 2011.

\begin{tabular}{|c|c|c|c|c|c|c|}
\hline \multirow[b]{2}{*}{ Variable } & \multicolumn{2}{|c|}{ F1 } & \multicolumn{2}{|c|}{$\mathrm{F} 2$} & \multicolumn{2}{|c|}{ F3 } \\
\hline & 2001 & 2011 & 2001 & 2011 & 2001 & 2011 \\
\hline University studies (25-64) & -1.0 & -1.0 & & & & \\
\hline Professionals & -0.9 & -0.9 & & & & \\
\hline No Secondary Education (20-64) & 0.9 & 0.9 & & & & \\
\hline Temporary contract & 0.9 & 0.7 & & & & \\
\hline Craft and related trades workers & 0.9 & 0.9 & & & & \\
\hline Service and sales workers & 0.9 & 0.8 & & & & \\
\hline Plant and machine operators and assemblers & 0.8 & 0.8 & & & & \\
\hline Inactive persons (45-64) & 0.8 & 0.5 & & & & \\
\hline Unemployed persons & 0.7 & 0.8 & & & & \\
\hline Average area per occupant & -0.7 & -0.6 & & & & \\
\hline Elementary occupations & 0.7 & 0.8 & & & & \\
\hline More than one hour (commuting) & 0.6 & 0.8 & & & & \\
\hline No lift (more than 3 floors) & 0.5 & 0.6 & & & & \\
\hline Children (0-14) & & & -0.9 & -0.9 & & \\
\hline Home with mortgage & & & -0.9 & -0.9 & & \\
\hline Aged 64 to 74 & & & 0.8 & 0.9 & & \\
\hline Aged over 75 & & & 0.8 & 0.7 & & \\
\hline Single mother households & & & 0.8 & 0.6 & & \\
\hline Housing paid for & & & 0.7 & 0.8 & -0.5 & \\
\hline Rental housing & & & & & 0.7 & 0.8 \\
\hline Born abroad (non-OECD) & & & & & 0.7 & 0.8 \\
\hline Buildings in poor condition & & & & & 0.7 & 0.5 \\
\hline Empty housing & & & & & 0.6 & 0.6 \\
\hline
\end{tabular}

Source: Drawn up by the authors based on the 2001 and 2011 Population and Housing censuses (INE, 2004, 2013).

characteristics, in other words, the presence of features of privilege excludes those of vulnerability and vice versa. Thus, socio-economic privilege involves more time availability, less difficulty in accessing housing, and more space in the home for each inhabitant whereas the opposite is linked to socio-economic vulnerability.

The second dimension (household life cycle) refers to the type of household that inhabits each ATU. Specifically, it distinguishes (and mutually excludes, as it is also a bipolar component) spaces including ageing and single-mother households, on the one hand, and spaces where children live in homes that are pending payment (through mortgage credit), on the other. The third component points to those territories with a high percentage of populations born in economically impoverished countries, which are also characterised by precarious residential conditions. This association is linked to the fact that the main access to housing is through private rental, due to the conditions imposed by the migratory path of these residents and the dynamics of the Spanish housing market in the first decade of the 21st century (Leal \& Alguacil, 2012).

The stability of these factors from 2001 to 2011 is significant here. In this respect, the 23 variables introduced in the model remain grouped in the same factor in both years. Also, the factorial structure and saturation of each variable in this dimension are similar in both years (the positive/negative orientation remains unchanged). Thus, we can assume that each of the three dimensions of the index measures the same latent concept on both dates and that, therefore this measuring instrument can be used to explain the processes of change across time and space.

\subsection{Trajectories of Social Residential Change (2001-2011)}

For 2001, the areas of the Community of Madrid were divided into three working-class types and three privileged-class types (according to the origin and age structure of its population, in each type), together with a socially mixed type (in each of the components of the social residential inequality index), as shown in Table 2. This division is based on the average value of each socio-residential type in the first dimension (the socioeconomic position) extracted by factor analysis. In this regard, a value close to zero in this component indicates a socio-economic position similar to that of the metropolitan area of Madrid as a whole. On the other hand, values far from zero in this component indicate an impoverished socio-economic profile (if it adopts positive values) or privileged (if they are negative).

In the case of 2011, the SRT differentiate the Madrid region into two variants (according to the diversity of 
Table 2. Centre of each SRT in each social residential inequality factor.

\begin{tabular}{lcrrr}
\hline Social Residential Type & F1 & F2 & F3 & Total \\
\hline SRT1 Diverse ageing working classes & 0.8 & 0.5 & 0.6 & 85 \\
SRT2. Young native working classes & 0.7 & -1.0 & -0.3 & 84 \\
SRT3. Ageing native working classes & 0.6 & 0.6 & -0.8 & 109 \\
SRT4. Socially and ethnically mixed spaces & 0.2 & 0.4 & 2.7 & 25 \\
SRT5. Young upper-middle classes & -0.9 & -1.5 & 0.2 & 71 \\
SRT6. Ageing privileged classes with immigration & -1.1 & 1.0 & 0.7 & 53 \\
SRT7. Native privileged classes & -1.2 & 0.5 & -0.8 & 61 \\
\hline
\end{tabular}

Source: Drawn up by the authors based on the 2001 and 2011 Population and Housing censuses (INE, 2004, 2013).

origin of the population, in each case) of the young working classes, the ageing lower-middle classes and the upper-middle classes, alongside an axis of privilege (Table 3). The disappearance of the socially and ethnically mixed spaces that were identified in 2001 is crucial in terms of segregation.

Overall, a transformation was identified in the social residential division of Madrid's metropolitan space, through which the consolidation of an axis of privilege can be observed, along with two types of particularly disadvantaged space. Certain processes of social change can be observed in four intermediate spaces. Both stability and change are articulated through the main social residential trajectories in the territory of Madrid from 2001 to 2011. In concrete, eleven transformation patterns are identified, each of which represents over $3 \%$ of the total trajectories: all together constituting $83.0 \%$ of that total (Table 4).

These transformation patterns, or trajectories of social-residential inequality, can be classified into three main types (Table 5), each one characterised by a particular housing dynamic (Table 6).

These trajectories can be further expanded on as follows:

1. Trajectories of impoverishment:

- The precarization of extremely impoverished young natives [SRT2 to SRT1: 10.5\%]: These metropolitan and working-class areas are the territories where the socio-economic position of their inhabitants is most precarious. These territories

Table 3. Centre of each SRT for each social residential inequality factor (2011).

\begin{tabular}{lcrrr}
\hline Social Residential Type & F1 & F2 & F3 & Total \\
\hline SRT1. Young, native, highly precarious classes & 1.1 & -0.5 & -0.5 & 80 \\
SRT2. Diverse highly precarious classes & 1.0 & -0.3 & 2.0 & 23 \\
SRT3. Diverse working classes & 0.6 & 0.5 & 0.6 & 82 \\
SRT4. Ageing native lower-middle classes & 0.4 & 1.1 & -1.0 & 78 \\
SRT5. Young native upper-middle classes & -0.5 & -1.5 & -0.4 & 88 \\
SRT6. Diverse upper-middle classes & -0.6 & 0.3 & 1.6 & 45 \\
SRT7. Ageing privileged classes & -1.3 & 0.5 & -0.1 & 93 \\
\hline
\end{tabular}

Source: Drawn up by the authors based on the 2001 and 2011 Population and Housing censuses (INE, 2004, 2013).

Table 4. Percentage of ATUs according to their SRT in 2001 and 2011.

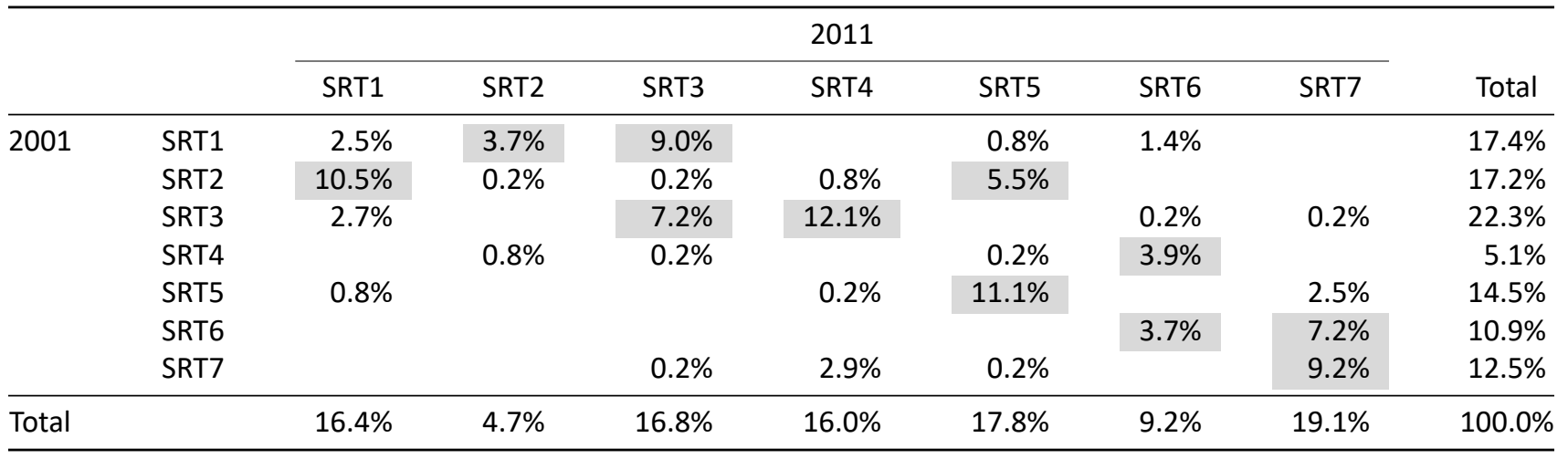

Source: Drawn up by the authors based on the 2001 and 2011 Population and Housing censuses (INE, 2004, 2013). 
Table 5. Social residential inequality index according to the type of social residential trajectory.

\begin{tabular}{|c|c|c|c|c|c|c|}
\hline \multirow[b]{2}{*}{ Trajectory } & \multicolumn{2}{|c|}{ F1 } & \multicolumn{2}{|c|}{$\mathrm{F} 2$} & \multicolumn{2}{|c|}{ F3 } \\
\hline & 2001 & 2011 & 2001 & 2011 & 2001 & 2011 \\
\hline Precarization of extremely impoverished young natives & 0.9 & 1.1 & -0.9 & -0.7 & -0.4 & -0.6 \\
\hline Ethnic enclaves & 1.1 & 1.0 & 0.6 & -0.2 & 1.1 & 2.0 \\
\hline Consolidation of early immigration & 0.8 & 0.7 & 0.5 & 0.4 & 0.4 & 0.7 \\
\hline Incorporation of migrants into working-class areas & 0.6 & 0.6 & 0.8 & 0.7 & -0.5 & 0.5 \\
\hline Impenetrable native working-class areas & 0.5 & 0.6 & 0.5 & 1.1 & -1.0 & -0.9 \\
\hline Incipient metropolitan gentrification & 0.5 & 0.2 & -1.2 & -1.6 & 0.0 & -0.4 \\
\hline Socio-economic improvement in the urban centre & 0.0 & -0.5 & 0.6 & 0.1 & 2.7 & 1.9 \\
\hline Expansion of native affluent peripheries & -0.9 & -0.8 & -1.7 & -1.5 & 0.3 & -0.4 \\
\hline Permeability to ethnic minorities in affluent areas & -0.8 & -0.9 & 1.0 & 0.5 & 1.0 & 1.4 \\
\hline Persistent privilege for relatively mixed groups & -1.3 & -1.3 & 0.9 & 0.7 & 0.5 & 0.4 \\
\hline Persistent native privilege & -1.4 & -1.3 & 0.5 & 0.6 & -0.6 & -0.5 \\
\hline Total & 0.0 & 0.0 & 0.0 & 0.0 & 0.0 & 0.0 \\
\hline
\end{tabular}

Source: Drawn up by the authors based on the 2001 and 2011 Population and Housing censuses (INE, 2004, 2013).

are, to a large extent, made up of housing built between 2001 and 2011. As a result, in 2011, people living in homes with a mortgage accounted for $43.1 \%$ of the total. Given the social composition of these spaces, residential growth during the said decade was based on the expansion of the mortgage supply to young native households in a precarious economic situation. This configuration has posed a considerable risk of eviction and impoverishment since the bursting of the housing bubble.

- The formation of ethnic enclaves [SRT1 to SRT2: 3.7\%]: These are working-class areas where people of the same ethnic minority come together in search of social networks, shared services, and a sense of security (Feijten \& van Ham, 2009). This process was already happening in 2001 and became consolidated with an intensity that led to a rejuvenation of the age structure and a shift in the socio-economic structure towards increased precariousness. A high percentage of the population residing in these ethnic enclaves lived in rental housing in 2011. This pattern is common to the following two types of trajectories (with a significant presence of migrants). In this regard, the percentage of people living in rental housing is directly proportional to the intensity of the settlement of the migrant population.

- The consolidation of early immigration in workingclass areas [SRT1 to SRT3: 9.0\%]: This involves a similar process to those described above but at a lower intensity.

- The incorporation of migrants into working-class areas [SRT3 to SRT3: 7.2\%]: These are workingclass areas where there was an intense settlement of impoverished migrants whose presence

Table 6. Relative increase of main dwellings (2001-2011) and tenure structure (2011) according to the type of social residential trajectory.

\begin{tabular}{|c|c|c|c|c|}
\hline \multirow[b]{2}{*}{ Trajectory } & \multirow[b]{2}{*}{$\begin{array}{c}\text { Increase in } \\
\text { Housing }\end{array}$} & \multicolumn{3}{|c|}{ Tenure Structure } \\
\hline & & $\begin{array}{l}\text { Housing } \\
\text { paid for }\end{array}$ & $\begin{array}{l}\text { Home with } \\
\text { Mortgage }\end{array}$ & $\begin{array}{c}\text { Rental } \\
\text { Housing }\end{array}$ \\
\hline Precarization of extremely impoverished young natives & 49.2 & 35,8 & 43,1 & 15,2 \\
\hline Ethnic enclaves & 14.9 & 31,5 & 30,0 & 29,9 \\
\hline Consolidation of early immigration & 9.6 & 39,5 & 28,8 & 22,6 \\
\hline Incorporation of migrants into working-class areas & 9.4 & 44,2 & 25,4 & 21,9 \\
\hline Impenetrable native working-class areas & 6.2 & 53,7 & 25,0 & 14,5 \\
\hline Incipient metropolitan gentrification & 173.9 & 20,3 & 59,4 & 14,8 \\
\hline Socio-economic improvement in the urban centre & 25.3 & 27,6 & 23,8 & 37,1 \\
\hline Expansion of native affluent peripheries & 153.0 & 25,0 & 56,1 & 14,0 \\
\hline Permeability to ethnic minorities in affluent areas & 16.1 & 33,8 & 21,8 & 31,8 \\
\hline Persistent privilege for relatively mixed groups & 12.8 & 37,5 & 22,8 & 23,5 \\
\hline Persistent native privilege & 18.6 & 45,2 & 28,9 & 15,1 \\
\hline Total & 49.1 & 36,1 & 37,9 & 18,2 \\
\hline
\end{tabular}

Source: Drawn up by the authors based on the 2001 and 2011 Population and Housing censuses (INE, 2004, 2013). 
was not significant in 2001 . These last three trajectories reflect processes involving the substitution of the Spanish population of lower-middle classes by impoverished foreign migrants as a result of the opportunities provided by the housing bubble to the former and the lack of options of the latter (Módenes, 2007). The substitution process is deduced from the important population change in the context of low residential growth.

- Impenetrable native working-class areas [SRT3 to SRT4: $12.1 \%$ ]: These are spaces where the autochthonous working classes, whose socioeconomic position is slightly deteriorating, age in houses in relatively adequate condition, which leads to their anchorage to the territory and explains the absence of substitution dynamics (Uceda, Sorando, \& Leal, 2018). This configuration makes these the territories with the highest percentage of people who reside in properties already paid for, as well as the spaces with the lowest residential growth between 2001 and 2011.

\section{Trajectories of gentrification:}

- Incipient metropolitan gentrification [SRT2 to SRT5: $5.5 \%$ ]: These are previously precarious metropolitan areas that are being transformed through rejuvenation and a significant improvement in the socio-economic conditions of their populations, as a result of processes of new construction (with an increase of $173.9 \%$ in the number of main dwellings from 2001 to 2011, which imply a proliferation of mortgages, placing these territories as those with the highest percentage of people in dwellings with a mortgage in 2011). These processes exploit the land regulations promoted by the real estate bubble to capitalise on new potential income gaps through new-build gentrification processes (Davidson \& Lees, 2010).

- Socio-economic improvement in the urban centre [SRT4 to SRT6 3.9\%]: These are the areas with the greatest increase in socio-economic position, a transformation that brought an end to social and ethnic mixing in 2001. This dynamic is facilitated by major urban regeneration and marketing processes in this territory, as well as by the importance of rental housing among its residents. Different case studies on transformations to these territories point to the gentrification processes as the cause of this change (García-Pérez, 2014).

\section{Trajectories of privilege:}

- Expansion of native affluent peripheries [SRT5 to SRT5 11.1\%]: These are affluent spaces where the main shift relates to the notable decrease in the proportion of migrants in rented housing as a result of the proliferation of new owner-occupied residences (main dwellings increased by $153.0 \%$ in the period studied, while the percentage of residents in homes with a mortgage in 2011 is the second-highest among the analysed trajectories).

- Permeability to ethnic minorities in affluent areas [SRT6 to SRT6: 3.7\%]: The continuation of the process of arrival of impoverished migrants to uppermiddle-class affluent territories where a certain degree of mixing is possible and thus, a process of rejuvenation also occurs. Such permeability to migrants finds its conditions of possibility in the significant presence of rental housing in these territories.

- Persistent privilege for relatively mixed groups [SRT6 to SRT7: 7.2\%]: The rejuvenation of the privileged population, in social residential terms, in spaces with a certain degree of ethnic diversity, also facilitated by a notable stock of rental housing.

- Persistent native privilege: [SRT7 to SRT7: 9.2\%]: Ageing of the privileged population in socio-residential terms and homogeneity in its autochthonous origin. These are territories with little residential growth and significant weight of already paid-for owned homes.

The geography of these trajectories confirms the traditional (privileged) northwest-southeast (impoverished) axes of the Community of Madrid, and yet it also introduces variants that confirm the dynamic nature of unequal socio-spatial configurations (Figure 1). Among these variants, the disappearance of the socially mixed spaces in the city centre stands out. The combination of the improvement in the socio-economic position of its inhabitants with its central location feeds the hypothesis of the gentrification of these spaces (Figure 2).

\subsection{Interlinked Inequalities}

Residential segregation processes tend to distribute households with disadvantaged socioeconomic status to residential settings with an unfavourable mix of advantages and disadvantages. The analysis of the dimensions of social residential inequality has revealed that the spaces which concentrate populations in a weaker socio-economic position are those whose housing (due to its surface area and conditions of physical access) and location (in relation to the main centres of employment) constitute a greater disadvantage. Thus, residential segregation, which to a large extent is the result of social inequality, contributes additional specific mechanisms towards its own reproduction, in a chain of inequality processes that takes the form of a vicious circle (van Ham et al., 2018).

In this respect, the high percentage of residents who have to spend more than one hour commuting from their homes to work means that in neighbourhoods with the highest concentration of impoverished households, the time available for activities with the potential to 


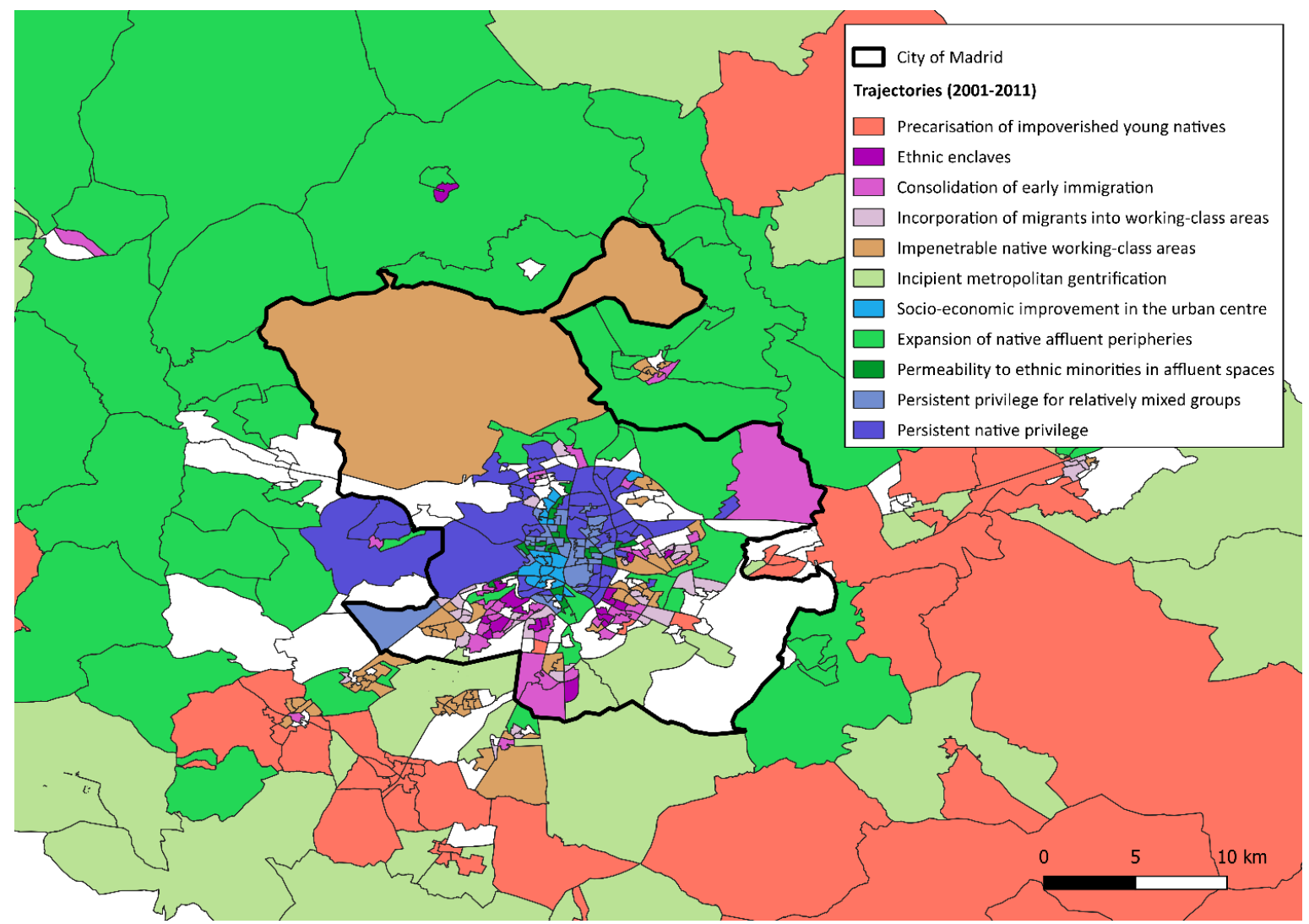

Figure 1. Main trajectories of social residential change (2001-2011) in the Region of Madrid. Source: Drawn up by the authors based on the 2001 and 2011 Population and Housing censuses (INE, 2004, 2013).

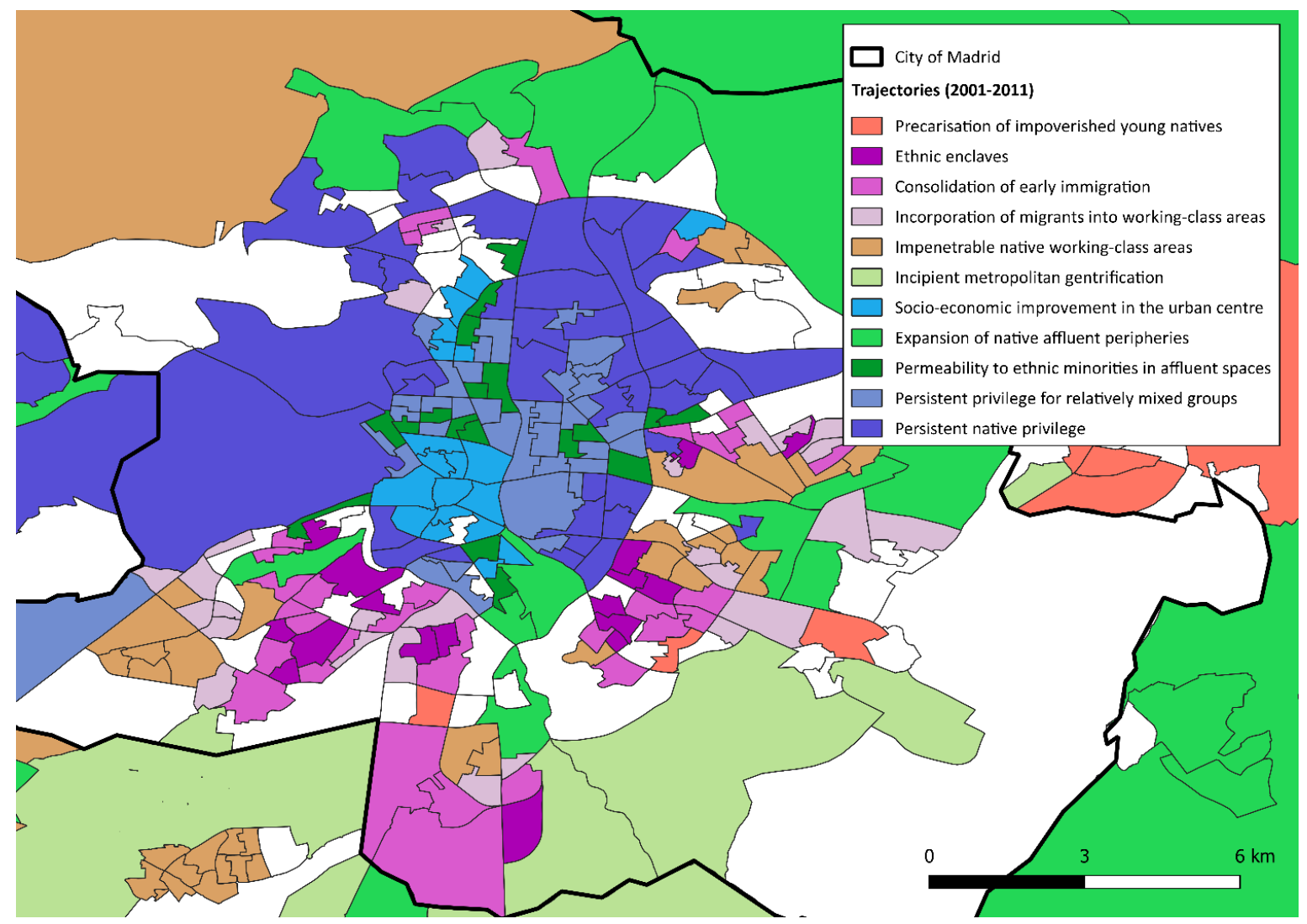

Figure 2. Main trajectories of social residential change (2001-2011) in the city of Madrid. Source: Drawn up by the authors based on the 2001 and 2011 Population and Housing censuses (INE, 2004, 2013). 
correct socio-economic inequality (such as education or family support) as well as the access to key services and social inclusion mechanisms are reduced (Church et al., 2000). Similarly, the lack of space for activities that require privacy, especially for those related to education and employment, constitutes a barrier to success for populations living in neighbourhoods in these areas. Overcrowded houses involve a lack of space for study, as well as high noise levels with significant impacts on concentration and sleeping that are related to psychological and school problems among children (Solari \& Mare, 2012). This is particularly relevant in the current context of the global COVID-19 pandemic, as well as in the social changes and inequalities it projects into the future concerning teleworking and online education (Beaunoyer, Dupéré, \& Guitton, 2020). In line with the uneven challenges posed by the COVID-19 pandemic, it is significant that the partial confinement of the population of the Community of Madrid during the autumn of 2020 was concentrated in the neighbourhoods in the southeast of the region, where the main trajectories of impoverishment are to be found. Lastly, physical isolation poses a threat to people with reduced mobility in the most impoverished neighbourhoods and has significant effects on their physical and mental health.

As per the associations observed in the social residential inequality dimension analysis, trajectories leading to concentrations of residents in weaker socio-economic positions are those in which these specific mechanisms of inequality reproduction are concentrated (Table 7). The distribution of these mechanisms in impoverishment trajectories, however, is not homogeneous. Here the accumulation of difficulties in impoverishment trajectories permeable to the settlement of precarious migrants stands out, with particularly high values of physical isolation which confirm their social residential marginalisation. In contrast, in the rest of the impoverished trajectories, characterised by the protagonism of the autochthonous population, physical isolation and lack of space are less intense. Gentrification trajectories, on the other hand, combine advantages with specific disadvantages (relating to location in the peripheries, and physical isolation in the urban centre). Meanwhile, privileged trajectories enjoy above-average advantages in terms of each of these mechanisms.

\section{Conclusion}

From 2001 to 2011, residential segregation grew in parallel with social inequality in the Madrid metropolitan area. The results of this article reveal eleven significant trajectories within which different processes of sociospatial change have operated, according to the classification of van Ham et al. (2012). Overall, during this period, two external shocks increased residential mobility in the region and explained many of the social residential changes: the real estate bubble and the arrival of significant numbers of international migrants (Bayona \& Pujadas, 2014).

Of all the trajectories of impoverishment, the processes of residential mobility in the southeast of the region stand out: those of young natives towards the newly built peripheries and, to an even greater extent, those of migrants towards houses abandoned by autochthonous residents in search of higher quality residential environments. The social residential trajectory of the latter involves a process of centrifugal expulsion from the city centre into the successive rings of the metropolitan areas (Arbaci, 2019). In this context, the only exception to the residential mobility among the trajectories of impoverishment is the ageing in-situ of native working classes in those neighbourhoods where residential conditions were acceptable. Regarding the trajectories of gentrification, residential mobility is stimulated by external impacts on processes of socio-economic improvement in the urban centre (which remove the only remaining spaces of social mixing left in the region) and new-build gentrification in the periphery.

Table 7. Average percentage of the variables of lack of time, available space and physical isolation, according to the trajectory of social residential inequality (2011).

\begin{tabular}{lccc}
\hline Trajectory & Lack of time & Space Available & Physical Isolation \\
\hline Precarization of extremely impoverished young natives & 15.1 & 32.5 & 23.2 \\
Ethnic enclaves & 12.4 & 25.4 & 72.1 \\
Consolidation of early immigration & 14.2 & 28.6 & 57.3 \\
Incorporation of migrants into working-class areas & 14.7 & 28.4 & 51.8 \\
Impenetrable native working-class areas & 14.9 & 30.3 & 35.3 \\
Incipient metropolitan gentrification & 14.7 & 36.9 & 11.1 \\
Socio-economic improvement in the urban centre & 5.2 & 34.3 & 37.4 \\
Consolidation of native affluent peripheries & 10.5 & 40.8 & 8.0 \\
Permeability to ethnic minorities in affluent areas & 8.2 & 36.4 & 16.1 \\
Persistent privilege for relatively mixed groups & 4.1 & 40.7 & 9.0 \\
Persistent native privilege & 9.0 & 41.1 & 8.7 \\
Total & 12.0 & 35.1 & 27.2 \\
\hline
\end{tabular}

Source: Drawn up by the authors based on the 2001 and 2011 Population and Housing censuses (INE, 2004, 2013). 
Finally, trajectories of privilege are characterised by the persistence of privilege, based on processes of ageing in-situ and residential mobility segmented by socioeconomic position. In short, the disappearance of spaces of social mixing is complemented, on the one hand, by the expansion of spaces of persistent privilege and, on the other hand, by the division of the trajectories of impoverishment according to the residential quality of each area in the southeast of the region. For the latter, this division leads migrant households to the most disadvantaged environments, where they join the autochthonous population hardest hit by this social residential model to share in the specific mechanisms of inequality reproduction linked to segregation. In this article, we have investigated some of these mechanisms, such as time poverty, overcrowding and physical isolation. Together with these, it is important to point out the symbolic mechanisms with the potential to reproduce inequality in the spaces of advanced marginality. In this regard, the concentration of this regime of poverty in clearly known and recognised territories produces discourses of defamation about these spaces. The consequence is the superposition of the neighbourhood taint to the rest of the stigmas assigned on the poverty and ethnic diversity of its inhabitants (Wacquant, 2008). Marcuse and van Kempen (2002) argue that spatial divisions not only reflect the divisions in society, but also help to create them, given that the decline in social mixing fosters prejudices based on the lack of significant daily interactions.

According to the results obtained, it is open to new research to investigate whether some of the spaces that host the most precarious socio-residential trajectories, with an important role of migrants, such as ethnic enclaves, could suffer from territorial stigmatisation, redoubling the disadvantages that its inhabitants carry in their daily lives. If we add to this the unequal effects of the great recession which began in 2008 , the scenario of the following decade entails dynamics of deepening inequality, given the concentration of the brunt of the recession's impact in the southeast of Madrid, which included the largest drops in employment (Rubiales, 2016) and property value (Sorando \& Leal, 2019), as well as the evictions (Méndez, 2017). In a context of abandonment of social housing in the region and a strategic commitment by financial actors to renting, future research should explore the unequal burden this implies and how it underlines or mitigates the different trajectories of social residential inequality.

\section{Acknowledgments}

Publication of this article was funded by both the Spanish Ministry of Science, Innovation and Universities (CSO2017-83968-R CAMVIVSOC) and the European Social Fund and the Community of Madrid (H2019/HUM5738 COMURES-CM). We thank the anonymous reviewers for their valuable and constructive comments.

\section{Conflict of Interests}

The authors declare no conflict of interests.

\section{References}

Alberdi, B. (2014). Social housing in Spain. In K. Scanlon, C. Whitehead, \& M. F. Arrigoitia (Eds.), Social housing in Europe (pp. 223-237). Chichester: John Wiley and Sons.

Allen, J., Barlow, J., Leal, J., Maloutas, T., \& Padovani, L. (2004). Housing and welfare in Southern Europe. Oxford: Blackwell.

Antolín-Iria, J. E., \& Fernández-Sobrado, J. M. (2020). Segregación residencial, políticas de vivienda y rentas familiares en épocas de transformación urbana: Bilbao 1991-2011 [Residential segregation, housing policies and family income in times of urban transformation: Bilbao 1991-2011]. Ciudad y Territorio, 52(205), 529-544. https://doi.org/10.37230/CyTET. 2020.205 .06

Arbaci, S. (2019). Paradoxes of segregation: Housing systems, welfare regimes and ethnic residential change in Southern European cities. London: Wiley Blackwell.

Bayona, J., \& Pujadas, I. (2014). Movilidad residencial y redistribución de la población metropolitana: Los casos de Madrid y Barcelona [Residential mobility and redistribution of the metropolitan population: The cases of Madrid and Barcelona]. EURE, 40(119), 261-287. http://dx.doi.org/10.4067/S025071612014000100012

Bayrakdar, S., Coulter, R., Lersch, P., \& Vidal, S. (2019). Family formation, parental background and young adults' first entry into homeownership in Britain and Germany. Housing Studies, 34(6), 974-996. https:// doi.org/10.1080/02673037.2018.1509949

Beaunoyer, E., Dupéré, S., \& Guitton, M. J. (2020). COVID19 and digital inequalities: Reciprocal impacts and mitigation strategies. Computers in Human Behavior, 111. https://doi.org/10.1016/j.chb.2020.106424

Cano, G., Etxezarreta, A., Dol, K., \& Hoekstra, J. (2013). From housing bubble to repossessions: Spain compared to other west European countries. Housing Studies, 28(8), 1197-1217. https://doi.org/10.1080/ 02673037.2013 .818622

Castells, M. (2003). European cities, the informational society and the global economy. In D. Leon, W. Heinemeijer, \& D. van Vaart (Eds.), Understanding Amsterdam: Essays on economic vitality, city life and urban form (pp. 1-18). Amsterdam: Het Spinius.

Castles, F., \& Ferrera, M. (1996). Home ownership and the welfare state: Is Southern Europe different? South European Society and Politics, 1(2), 163-185. https://doi.org/10.1080/13608749608539470

Church, A., Frost, M., \& Sullivan, K. (2000). Transport and social exclusion in London. Transport Policy, 7, 195-205.

Davidson, M., \& Lees, L. (2010). New-build gentrifica- 
tion: Its histories, trajectories, and critical geographies. Population, Space and Place, 16(5), 395-411. https://doi.org/10.1002/psp.584

Delbosc, A., \& Currie, G. (2011). The spatial context of transport disadvantage, social exclusion and well-being. Journal of Transport Geography, 19(6), 1130-1137. https://doi.org/10.1016/j.jtrangeo. 2011.04.005

Domínguez, M., Leal, J., \& Martínez, E. (2012). The limits of segregation as an expression of socioeconomic inequality: The Madrid case. In T. Maloutas \& K. Fujita (Eds.), Residential segregation in comparative perspective: Making sense of contextual diversity (pp. 217-236). Farnham: Ashgate.

Feijten, P. M., \& van Ham, M. (2009). Neighbourhood change...reason to leave? Urban Studies, 46, 2103-2122. https://doi.org/10.1177/0042098 009339430

Fernandez, R., \& Aalbers, M. B. (2016). Financialization and housing: Between globalization and varieties of capitalism. Competition \& Change, 20(2), 71-88. https://doi.org/10.1177\%2F1024529415623916

FOESSA. (2019). VIII Informe sobre exclusión y desarrollo social en España [8th report on exclusion and social development in Spain]. Madrid: FOESSA.

Frey, W. (2014). Diversity explosion: How new racial demographics are remaking America. Washington, DC: Brookings Institution Press.

Fujita, K., \& Hill, R. C. (2012). Residential income inequalities in Tokyo and why it does not translate into class-based segregation. In T. Maloutas \& K. Fujita (Eds.), Residential segregation in comparative perspective: Making sense of contextual diversity (pp. 37-68). Farnham: Ashgate.

García-Pérez, E. (2014). Gentrificación en Madrid: De la burbuja a la crisis [Gentrification in Madrid: From the bubble to the crisis]. Revista de Geografía Norte Grande, 58, 71-91. http://dx.doi.org/10.4067/ S0718-34022014000200005

García-Lamarca, M., \& Kaika, M. (2016). 'Mortgaged lives': The biopolitics of debt and housing financialization. Transactions of the Institute of British Geographers, 41(3), 313-327. https://doi.org/10.1111/tran. 12126

Hartschorn, T. A. (1992). Interpreting the city: An urban geography. New York, NY: John Wiley.

Holt-Lunstad, J., Smith, T. B., \& Layton, J. B. (2010). Social relationships and mortality risk: A meta-analytic review. PLoS Medicine, 7. https://doi.org/10.1371/ journal.pmed.1000316

INE. (2004). Censo de población y viviendas 2001. Resultados definitivos [Population and housing census 2001. Final results; Data set]. Retrieved from https:// www.ine.es/censo/es/inicio.jsp

INE. (2011). Encuesta de condiciones de vida. Resultados [Life conditions survey. Results; Data set]. Retrieved from https://www.ine.es/jaxiT3/Datos.htm?t=9994

INE. (2013). Censo de población y viviendas 2011. Datos detallados [Population and housing census 2011. Detailed data; Data set]. Retrieved from https:// www.ine.es/censos2011/tablas/Inicio.do

Kaufmann, V., Bergman, M., \& Joye, D. (2004). Motility: Mobility as capital. International Journal of Urban and Regional Research, 28(4), 745-756. https://doi. org/10.1111/j.0309-1317.2004.00549.x

Kesteloot, C. (2005). Urban socio-spatial configurations and the future of European cities. In Y. Kazepov (Ed.), Cities of Europe: Changing contexts, local arrangements, and the challenge to urban cohesion (pp. 123-148). London: Routledge.

Leal, J., \& Alguacil, A. (2012). Vivienda e inmigración: Las condiciones y el comportamiento residencial de los inmigrantes en España [Housing and immigration: The residential conditions and behaviour of immigrants in Spain]. In E. Aja, J. Arango, \& J. Oliver (Eds.), La hora de la integración. Anuario de la Inmigración en España. Edición 2011 [The time of integration. Yearbook of immigration in Spain. 2011 edition] (pp. 126-156). Barcelona: Fundación CIDOB.

López, I., \& Rodríguez, E. (2011). The Spanish model. New Left Review, 69, 5-29.

Malheiros, J. M., \& Fonseca, L. (2011). Acesso à habitação e problemas residenciais dos imigrantes em Portugal [Access to housing and residential problems of immigrants in Portugal]. Lisbon: ACIDI-High Commission for Immigration and Intercultural Dialogue.

Marcuse, P., \& van Kempen, R. (2000). Globalizing cities: A new spatial order? Malden, MA: Blackwell.

Marcuse, P., \& van Kempen, R. (eds.) (2002). Of states and cities: The partitioning of urban space. Oxford: Oxford University Press.

Méndez, R. (2017). De la hipoteca al desahucio: Ejecuciones hipotecarias y vulnerabilidad territorial en España [From mortgage to eviction: Foreclosures and territorial vulnerability in Spain]. Revista de Geografía Norte Grande, 67, 9-31. http://dx.doi.org/ 10.4067/S0718-34022017000200002

Módenes, J. A. (2007). Una visión demográfica de la movilidad residencial reciente en España [A demographic view of recent residential mobility in Spain]. In J. M. Feria (Ed.), La vivienda y el espacio residencial en las áreas metropolitanas [Housing and residential space in metropolitan areas] (pp. 15-32). Sevilla: Centro de Estudios Andaluces.

Musterd, S. (2003). Segregation and integration: A contested relationship. Journal of Ethnic and Migration Studies, 29(4), 623-641. https://doi.org/10.1080/ 1369183032000123422

Piketty, T. (2013). Capital in the 21st century. Cambridge, MA: Harvard University Press.

Pittini, A. (2019). The state of housing in the EU. Brussels: Housing Europe.

Porcel, S., \& Antón, F. (2020). Ciudad postindustrial y dinámicas socio-residenciales en España: Un análisis comparativo de cinco metrópolis [Post-industrial city and socio-residential dynamics in Spain: A com- 
parative analysis of five metropolises]. Scripta Nova. Revista Electrónica de Geografía y Ciencias Sociales, 24. https://doi.org/10.1344/sn2020.24.29092

Rubiales, M. (2016). Territorio y crisis: Impacto territorial de la crisis económica en las regiones metropolitanas de Madrid y Barcelona [Territory and crisis: Territorial impact of the economic crisis in the metropolitan regions of Madrid and Barcelona]. Scripta Nova: Revista electrónica de Geografía y Ciencias sociales, 20(549). https://doi.org/10.1344/sn2016.20.17208

Rubiales, M. (2020). Segregación en las metrópolis españolas 2001-2011: Un análisis con detalle territorial [Segregation in the Spanish metropolises 20012011: An analysis with territorial detail]. Documents d'Anàlisi Geogràfica, 66(1), 83-105. https://doi.org/ 10.5565/rev/dag.581

Solari, C. D., \& Mare, R. D. (2012). Housing crowding effects on children's wellbeing. Social Science Research, 41, 464-476. https://doi.org/10.1016/ j.ssresearch.2011.09.012

Sorando, D., \& Leal, J. (2019). Distant and unequal: The decline of social mixing in Barcelona and Madrid. Revista Española de Investigaciones Sociológicas, 167, 125-148. http://dx.doi.org/10.5477/ cis/reis.167.125

Sorando, D., \& Uceda, P. (2018). Fragmentos urbanos después de la burbuja inmobiliaria: El caso de Madrid [Urban fragments after the real estate bubble: The case of Madrid]. OBETS. Revista de Ciencias
Sociales, 13(1), 383-410. https://doi.org/10.14198/ OBETS2018.13.1.14

Standing, G. (2011). The precariat: The new dangerous class. London: Bloomsbury Academic.

Tammaru, T., Marcińczak, S., van Ham, M., \& Musterd, S. (Eds.). (2016). Socio-economic segregation in european capital cities: East meets West. Oxford: Routledge.

Uceda, P., Sorando, D., \& Leal, J. (2018). The diversity of trajectories of large housing estates in Madrid, Spain. In D. Hess, T. Tammaru, \& M. van Ham (Eds.), Housing estates in Europe: Poverty, ethnic segregation and policy challenges (pp. 241-262). Dordrecht: Springer. van Ham, M., Manley, D., Bailey, N., Simpson, L., \& Maclennan, D. (Eds.). (2012). Understanding neighbourhood dynamics: New insights for neighbourhood effects research. Dordrecht: Springer.

van Ham, M., Tammaru, T., \& Janssen, H. (2018). A multilevel model of vicious circles of socio-economic segregation. In OECD (Eds.), Divided cities (pp. 135-153). Paris: OECD Publishing.

van Kempen, R., \& Bolt, G. (2012). Social consequences of residential segregation and mixed neighborhoods. In D. F. Clapham, W. A. V. Clark, \& K. Gibb (Eds.), The Sage handbook of housing studies (pp. 439-460). Los Angeles, CA: Sage.

Wacquant, L. (2008). Urban outcasts: A comparative sociology of advanced marginality. Cambridge, MA: Polity Press.

\section{About the Authors}

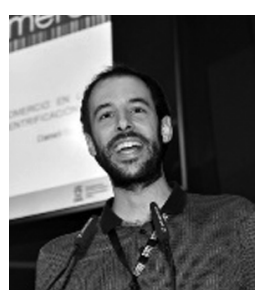

Daniel Sorando (PhD) is a Sociologist and an Assistant Professor in the Applied Sociology Department at Complutense University of Madrid. His research focus is on residential segregation and housing, with particular attention to gentrification processes and their link to inequality. He is co-author of First We Take Manhattan: La Destrucción Creativa de las Ciudades [First we take Manhattan: The Creative Destruction of Cities] (2016).

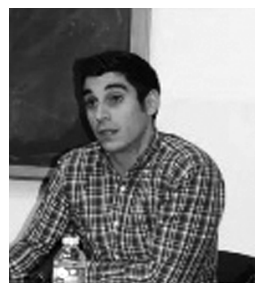

Pedro Uceda (PhD) is a Sociologist and an Adjunct Professor in the Applied Sociology Department at Complutense University of Madrid. His research focus is on the right to the city, socio-urban vulnerability, and segregation processes. Pedro Uceda has published several articles in peer-reviewed journals and contributed to different books. He is currently working as a researcher at the Conference of Spanish University Rectors (CRUE).

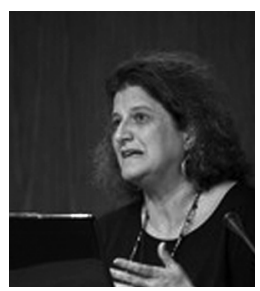

Marta Domínguez (PhD) is a Sociologist and an Associate Professor in the Applied Sociology Department at Complutense University of Madrid. Her research focus is on vulnerable groups in the city, public space, gendered cities, urban identity and cultural and urban heritage, and social segregation processes. She has been Head of different funded research projects, coordinator of the 4Cities Erasmus Mundus Master, coordinator member of the Urban Sociology Working Group of the Spanish Federation of Sociology (FES), editor of the peer-reviewed journal Society and Childhood and Head of the research group GISMAT. 